Marshall University

Marshall Digital Scholar

Biological Sciences Faculty Research

Biological Sciences

$10-1986$

\title{
Effects of Pituitary Stalk-transection and Type of Barrier on Pituitary and Luteal Function During the Estrous Cycle of the Ewe
}

David S. Mallory

Marshall University, mallory@marshall.edu

C. M. Gust

R.A. Dailey

Follow this and additional works at: http://mds.marshall.edu/bio_sciences_faculty

Part of the Animal Sciences Commons, and the Cell and Developmental Biology Commons

\section{Recommended Citation}

Mallory D. S., Gust C. M., Dailey R. A. (1986) Effects of pituitary stalk-transection and type of barrier on pituitary and luteal function during the estrous cycle of the ewe. Domest. Anim. Endocrinol. 3:253-259.

This Article is brought to you for free and open access by the Biological Sciences at Marshall Digital Scholar. It has been accepted for inclusion in Biological Sciences Faculty Research by an authorized administrator of Marshall Digital Scholar. For more information, please contact 


\section{EFFECTS OF PITUITARY STALK-TRANSECTION \\ AND TYPE OF BARRIER ON PITUITARY AND LUTEAL FUNCTION DURING THE ESTROUS CYCLE OF THE EWE}

D.S. Mallory, C.M. Gust and R.A. Dailey

Division of Animal and Vet. Science

West Virginia University

Morgantown, WV 26506-6108

Running title: Stalk-transection during the estrous cycle of the ewe

Key words: Pituitary Stalk-transection Luteal

Function, Ewe 


\begin{abstract}
Effects of pituitary stalk-transection on plasma concentrations of luteinizing hormone (LH), follicle stimulating hormone (FSH) prolactin (PRL) and progesterone were investigated during the estrous cycle of ewes. Pituitary stalk (SS) or sham (SH) transection was performed on day 1 (estrus = day 0) of the estrous cycle. A Teflon or Silastic barrier was placed between the cut ends of the stalk to prevent reorganization of the portal vasculature. Immediately following surgery, pulsatile administrations of gonadotropin releasing hormone (GnRH, 200ng/hr) or 0.9\% $\mathrm{NaCl}$ was initiated and continued for the duration of the experiment. Estradiol benzoate (EB, 50 ug im) was administered to all ewes on day 3. Mean concentrations of LH were greater in SS ewes than in $\mathrm{SH}$ ewes $(\mathrm{P}<. \mathrm{O} 5)$. There was a trend $(\mathrm{P}=.06)$ for the concentration of $\mathrm{LH}$ to be higher in ewes with Teflon compared with Silastic barriers between the cut ends of the stalk. Infusion of GnRH elevated concentrations of LH in both SS and SH ewes $(\mathrm{P}<.05)$.

Concentrations of progesterone were reduced $(\mathrm{P}<. \mathrm{O} 1)$ in saline infused SS ewes while infusion of GnRH in SS ewes maintained concentrations of progesterone similar to saline infused SH ewes. The concentrations of FSH or PRL were unaffected by SS, type of barrier or treatment with GnRH. Administration of EB failed to induce a surge of LH except in a SH ewe infused with GnRH. Ewes were more responsive to infusion of GnRH following SS than after SH as reflected by increased plasma concentrations of LH and progesterone.
\end{abstract}

\title{
INTRODUCTION
}

Pituitary stalk-transection (SS) has been used to create a pituitary island devoid of hypothalamic influence. A barrier placed between the cut ends of the stalk prevented revascularization of the portal system (1). Ferin et al. (2) and Knobil (3) using Silastic barriers demonstrated that infusion of estradiol elicited surges of luteinizing hormone (LH) and follicle stimulating hormone (FSH) in monkeys. Norman et al. (4) showed in vitro that Silastic was permeable to low molecular weight substances including gonadotropin releasing hormone (GnRH). Furthermore, when Silastic, but not Teflon, was used as the barrier in SS monkeys, systemic concentrations of estradiol were increased after 2 days of pulsatile administration of GnRH and menstrual cycles were restored. It was concluded that restoration of cyclicity $(2,3)$ was likely due to estradiol positive feed-back on the hypothalamus which elicited a surge of GnRH that penetrated the Silastic barrier and caused the release of gonadotropins (4). After SS of beef calves (5) or heifers (6), systemic concentrations of LH were decreased and follicular development was abolished. After infusion of $\mathrm{GnRH}, 40 \%$ of the heifers increased follicular size and one animal formed a corpus luteum (CL, 6).

Effects of lesions of specific brain areas and SS on concentrations of gonadotropins have been reported, but few of these studies have examined luteal function. Replacement of GnRH in brain-lesioned monkeys (7), raised tonic concentrations of gonadotropins and estradiol sufficiently to initiate surges of gonadotropins, ovulation and luteal function. Similar results were obtained in SS monkeys infused with GnRH and estradiol (4).

Difference between Silastic and Teflon as barriers against hypothalamic influence on pituitary function, the site of progesterone negative and estradiol positive feedback on secretion of gonadotropins and luteal function after pituitary stalk-transection were studied in ewes. 


\section{MATERIALS AND METHODS}

From October to January, 21 ewes of mixed breeding with normal estrous cycles (15-17 days) were transferred, as they were detected in estrus (day 0) by vasectomized rams, from pasture to the surgical facility. On day 1, ewes were anesthetized with sodium pentobarbital. Atropine sulphate $(15 \mathrm{mg} / \mathrm{im})$, was administered to reduce salivation. Nitrous oxide and oxygen/carbon dioxide (95:5) were administered via an endotracheal tube at a ratio of 2:1 with the maintenance dose of halothane at $0.5-1.0$ percent.

Transection of the pituitary talk (SS \} was by the transorbital approach of Gust (8). Briefly, following exenteration of the orbit, a dental drill was used to remove the bone between the optic foramen and the foramen orbitorotundum. The dura mater was cut to reveal the pituitary stalk (Sham stalk transection, $\mathrm{SH}, \mathrm{n}=6)$. The stalk was transected $(n=15)$ with Yasargil alligator scissors (V. Mueller, Linden, NJ) close to the pituitary and a stainless steel probe was passed between the severed ends to assure transection. Silastic $(n=9,6.5 \times 6.5 \times .508 \mathrm{~mm})$ or Teflon ( $\mathrm{n}=6,8 \times 7 \times 1 \mathrm{~mm})$ was placed between the cut ends of the stalk to maintain separation of the pituitary and hypothalamus. Cotton was placed in the orbit against the drilled area and saturated with cyanoacrylate to form a fluid-proof seal. Gel-Foam (The Upjohn Company, Kalamazoo, MI) was packed into the orbit and the eyelids were sutured closed.

Immediately following surgery, and for the next 3 days animals received $3 \mathrm{ml}(\mathrm{im})$ penicillin $\mathrm{G}$ procaine, U.S.P. $(200,000 \mathrm{IU} / \mathrm{ml})$ in a solution of dihydrostreptomycin sulfate $(0.25$ $\mathrm{mg} / \mathrm{ml}$ ). After recovery from anesthesia, ewes were stanchioned and infused, via jugular vein catheters, with either hourly pulses (1 min. duration) of $200 \mathrm{ng} \mathrm{GnRH}$ (Abbott Laboratories; SS, $\mathrm{n}=7$; $\mathrm{SH}, \mathrm{n}=3$ ) or an equal volume of physiological saline (SS, n=8; sa, $\mathrm{n}=3$ ) throughout the experiment. Ewes were transferred from temperature controlled holding rooms to an open air barn on days 4 or 5 .

All ewes received a $50 \mathrm{ug}$ bolus injection of estradiol benzoate (EB) in corn oil at $20.00 \mathrm{~h}$ on day 3. Plasma was harvested from blood samples collected hourly, from 06.00 through 20.00 $\mathrm{h}$ on day 4 and daily from day 5 through day 20 then stored at $-5^{\circ} \mathrm{C}$ until assayed for $\mathrm{LH}, \mathrm{FSH}$, prolactin (PRL) and progesterone

At necrospy completeness of transection and placement of the barriers was confirmed and ovaries were inspected for the presence of ovarian structures.

\section{Radioimmunoassays}

Previously validated radioimmunoassays were used to quantify concentrations of LH (9), FSH (10), PRL (11), and progesterone (12). Standard preparations were ovine LH (NIH-6LHS19), ovine FSH (NIAMDD-oFSH-RPI), ovine PRL (NIAMDO-oPRL-I-1) and progesterone (Sigma Corp., St. Louis, MO). Sensitivities of the assays for LH, FSH, PRL, and progesterone were $0.30 \mathrm{ng} / \mathrm{ml}, 0.25 \mathrm{ng} / \mathrm{ml}, 0.25 \mathrm{ng} / \mathrm{ml}$ and $0.10 \mathrm{ng} / \mathrm{ml}$, respectively. Intra-assay coefficients of variation were 4.1, 5.6, 5.1 and $12.6 \%$ respectively. The interassay coefficients of variation for LH and FSH were 5.2 and $7.1 \%$, respectively for three assays of each hormone. Samples were assayed for PRL and progesterone in single assays.

\section{Statistical Analyses}

Least-squares analysis of variance for a completely randomized split plot design with repeated measures in time was used to examine hormonal data (13). Factors in the main plot 
were type of barrier elnd treatment with GnRH or saline, while time and interactions with time were in the subplot. Data were analyzed through day 10 of the experimental period.

\section{RESULTS}

Infusion of $\mathrm{GnRH}$ as compared to saline elevated mean concentrations of LH from 10 to 24 hours after the administration of EB $(1.87 \pm .16$ vs. $0.70 \pm .15 \mathrm{ng} / \mathrm{ml} \mathrm{P}<.05)$. Concentrations of LH were increased in both SS and SH ewes by infusion of GnRH from day 5 through day 10, however mean concentrations of LH were higher in both groups of SS ewes when compared to all $\mathrm{SH}$ ewes $(\mathrm{P}<.05$, Fig. 1).

SH ewes which received GnRH infusion exhibited an elevation of mean LH during the subsequent follicular phase (day 16 through day 20) when compared to all SS ewes. SH ewes which received saline had increased concentrations of LH during this time, but not to the extent seen in GnRH infused SH ewes. Blood samples were collected too infrequently to fully characterize a surge but peak concentrations of LH in the three GnRH infused SH ewes were 8.33, 11.21 and $12.74 \mathrm{ng} / \mathrm{ml}$ while the two saline infused $\mathrm{SH}$ ewes, which displayed obvious increases, had concentrations of 1.84 and $3.82 \mathrm{ng} / \mathrm{ml}$. None of the three saline infused SS ewes nor the two GnRH infused animals which completed the 20 days, displayed an elevation of LH concentrations during the subsequent follicular phase.

Concentrations of progesterone were lower $(\mathrm{P}<.01)$ in SS ewes receiving saline than in any other group. Concentrations of progesterone were elevated by day 6 then plateaued at a lower concentration than $\mathrm{SH}$ ewes receiving saline $(1.06 \pm .11$ vs. $2.20 \pm .16 \mathrm{ng} / \mathrm{ml})$. Pulsatile administration of GnRH to SS ewes elevated $(\mathrm{P}<.05)$ mean concentrations of progesterone to values similar to $\mathrm{SH}$ controls. Administration of $\mathrm{GnRH}$ also elevated $(\mathrm{P}<.05)$ concentrations of progesterone in $\mathrm{SH}$ ewes. At days 15 and 16, $(\mathrm{SH}, \mathrm{n}=6 ; \mathrm{SS}, \mathrm{n}=\mathrm{S})$ the concentrations of progesterone declined rapidly as would be expected during the normal ovine estrous cycle (Fig.2).

There was a trend $(. \mathrm{P}=.06)$ for the concentrations of $\mathrm{LH}$ to be higher in all ewes which received Teflon as the barrier between the cut ends of the stalk when compared to ewes with Silastic barriers $(1.22 \pm .08 \mathrm{vs} .88 \pm .07 \mathrm{ng} / \mathrm{ml})$. Concentrations of FSH arid PRL, were unaffected by SS, type of barrier or treatment with GnRH. Administration of $50 \mathrm{~g}$ EB bad no effect on the mean concentration of $\mathrm{LH}$, with the exception that one SH ewe had a surge of $\mathrm{LH}$ (31 ng/ml) 17 hours after administration.

\section{DISCUSSION}

In contrast to the study by Norman et al. (4), there were no statistically significant differences between Silastic and Teflon as barriers to hypothalamic influence in ewes. Knobil and coworkers have shown that monkeys with Silastic barriers between the cut ends of the pituitary stalk could be stimulated to exhibit surges of gonadotropins and have menstrual cycles by infusing estrogen $(2,7)$. No SS ewes exhibited surges of LH during the follicular phase (day 16 through 20) even when infused with GnRH, however, surges of LH were evident in SH ewes during this period. At necropsy SS ewes had ovaries with corpora albicantia art limited follicular development, while SH ewes had formed new CL. 
Concentrations of L-H and progesterone were elevated in GnRH-infused ewes but concentrations of PRL were unaffected by SS or GnRH infusion. Immediately following SS or SH, plasma PRL was elevated; by 6 (8) or after 7 hours (14) post surgery concentrations of PRL returned to presurgery values. The luteotropic complex of LH and PRL is necessary for function of the CL in the ewe (15). As there was no difference in concentrations of PRL between GnRHor saline-infused ewes, the elevated concentrations of progesterone can be accounted for by the elevated LH. Synthesis of progesterone was stimulated by administration of LH in intact (15) and hypothalamo- pituitary stalk-disconnected ewes (16).

Progesterone inhibited LH via hypothalamic mechanisms as concentrations of LH in SS ewes with GnRH treatment were higher than in SH GnRH-treated ewes with comparable concentrations of progesterone. Tonic secretion of LH during the ovine estrous cycle was inversely related to circulating progesterone (17). Ovariectomy in the ewe induced rapid increases in the secretion of LH which could be blocked by subcutaneous implants of progesterone and the hypothalamus was suggested as the site of action (18). Receptors for progesterone have been characterized in the hypothalami of rats $(19,20)$ providing further evidence for a hypothalamic site of progesterone action.

Separate mechanisms for release 6f LH and FSH may exist in sheep. Plasma concentrations of LH and FSH declined following SS (21) but hourly intravenous pulses $(21,22)$ of GnRH which mimicked endogenous secretion (23) restored LH but not FSH to pre-surgery values. In the present study, hourly infusion of $200 \mathrm{ng}$ GnRH did not alter secretion of FSH but did increase concentrations of LH in SS ewes when compared to saline infused SS ewes. Increased amplitudes of pulses of exogenous GnRH raised basal LH, but had no effect on basal FSH, while decreased frequency of administration of GnRH decreased basal LH and increased basal FSH (22).

A single bolus injection of $50 \mathrm{ug}$ EB elicited a preovulatory-like surge in concentrations of LH when administered to ovariectomized ewes during the breeding season $(24,25)$. However, only one SH ewe which received pulsatile GnRH infusions exhibited a surge of LH in response to estrogen in the present study. A group of three intact ewes on day 3 of the estrous cycle (data not included) also failed to exhibit surges of LH. At this time of the estrous cycle, the hypothalamo-hypophyseal axis may be refractory or a higher dose of estrogen may be necessary to stimulate a surge. Bolt and coworkers (26) reported that a $1 \mathrm{mg}$ bolus injection of EB stimulated a surge of LH when administered on day 3 of the estrous cycle. Gust (8) demonstrated that injection of 400 ug EB 3 days after sham stalk sectioning in ovariectomized ewes elicited a surge of LH 18 hours later.

In summary, transection of the pituitary stalk of the ewes on day 1 of the estrous cycle resulted in reduced function of the CL but did not alter luteal lifespan. Function of the CL of SS ewe was enhanced by GnRH infusion as concentrations of progesterone were elevated in the GnRH infused ewes when compared to saline infused controls. This increased CL function was probably due to increased LH support for the CL, however, direct action of GnRH on the CL can not be ruled out. Lastly, progesterone apparently acts at the hypothalamus to inhibit secretion of LH in ewes. 


\section{ACKNOWLEDGEMENT'S}

The authors are grateful for the generous provisions of antisera to progesterone by Dr. R.L. Butcher, antiserum to LH by Dr. G.D. Niswender, Colorado State University, antiserum to FSH by NIADDK, antiserum to PRL by NIAMDD and purified preparations of LH by Dr. L.E. Reichart, Jr. Albany Medical College and FSH by NIADDK and PRL by NIAMDD. We thank The Upjohn Company for donation of Gel Foam and Abbott Laboratories for donation of GnRH. We are indebted to Dr. W.V. Thayne for assistance with statistical analysis, Drs. E.K. Inskeep, R.L. Butcher and R.L. Goodman critical reading of the manuscript, and Mary Ann Barnes for typing the manuscript.

\section{Address Correspondence}

R.A. Dailey, Division of Animal and Vet. Sci.,West Virginia University, Morgantown, WV. 26506-6108

\section{REFERENCES}

1. Harris GW. Oestrous rhythm. Pseudopregnancy and the pituitary stalk in the rat. J. Physiol. 111:347-360, 1950.

2. Ferin M, Rosenblatt H, Carmel PW, Antunes, JL and Van de Wiele RL. Estrogen induced gonadotropin surges in female rhesus monkeys after pituitary stalk section. Endocrinol. 104:50-52, 1979.

3. Knobil E. The neuroendocrine control of the menstrual cycle. Recent Prog. Horm. Res. 36:53-85, 1980.

4. Norman RL, Gliessman P, Lindstrom SA, Hill J and Spies HG. Reinitiation of ovulatory cycles in pituitary stalk-sectioned rhesus monkeys: evidence for a specific hypothalamic message for the preovulatory release of 1uteinizing hormone. Endocrinol. 111:1874$1882,1982$.

5. Anderson LL, Hard DL, Carpenter LS, Awotwi EK and Diekman MA. Neuroendocrine regulation of luteinizing hormone secretion in beef calves. Biol. Reprod. 24:795-800, 1981.

6. Awotwi EK, Keeney DS, Hard DL and Anderson LL. Effects of pulsatile infusion of luteinizing hormone- releasing hormone on luteinizing hormone secretion and ovarian function in hypophyseal stalk-transected beef heifers. Biol. Reprod. 31:989-999, 1984.

7. Knobil E, Plant TM, Wildt L, Belchetz PE and Marshall GL. Control of rhesus monkey menstrual cycle: permissive role of hypothalamic gonadotropin-releasing hormone. Science 207:1371-1373, 1980. 
8. Gust CM. Secretion of pituitary hormones in stalk-transected, ovariectomized ewes. Ph.D. Dissertation. West Virginia University, Morgantown, WV. pp. 40-41. 1985.

9. Fogwell RL, Lewis GS, Butcher RL and Inskeep EK. Effects of ovarian bisection on response to intrafollicular injection of PGF2 and on follicular development in ewes. J. Anim. Sci. 45:328-335, 1977.

10. Keisler DH, Inskeep EK, and Dailey RA. Roles of pattern of secretion of luteinizing hormone and the ovary in attainment of puberty in ewe lambs. Domestic Animal Endocrinology 2:123-132. 1985.

11. Deaver DR and Dailey RA. Effects of dopamine, norepinephrine and serotonin on plasma concentrations of luteinizing hormone and prolactin in ovariectomized and anestrous ewes. Biol. Reprod. 27:624-632, 1982.

12. Sheffel CE, Pratt BR, Ferrell WL and Inskeep EK. Induced corpora lutea in the postpartum beef cow. II. Effects of treatment with progestogen and gonadotropins. J. Anim. Sci. 54:830-836, 1982.

13. Gill JL, and Hafs HD. Analysis of repeated measurements of animals. J. Anim. Sci. 33:331-336, 1971.

14. Bryant GD, Greenwood FC, Kann G. Martinet J and Deriamur R. Plasma prolactin in the oestrous cycle of the ewe: effect of pituitary stalk section. J. Endocrinol. 51:405-406, 1971.

15. Niswender GD, Menon KMJ and Jaffe RB. Regulation of the corpus luteum during the menstrual cycle and early pregnancy. Fertility and Sterility 23:432-442, 1972.

16. Niswender GD, Farin CE, Gamboni F, Sawyer HR and Nett TM. Role of luteinizing hormone in regulating luteal function in ruminants. J. Anim. Sci. (In Press), 1985.

17. Hauger RL, Karsch FJ and Foster DL. A new concept for control of the estrous cycle of the ewe based on the temporal relationships between luteinizing hormone, estradiol and progesterone in peripheral serum and evidence that progesterone inhibits tonic $\mathrm{LH}$ secretion. Endocrinol. 101:807-817, 1977.

18. Karsch FJ, Legan SJ, Hauger RL and Foster DL. Negative feedback action of progesterone on tonic luteinizing hormone secretion in the ewe: dependence upon the ovaries. Endocrinol. 101:800-806, 1977.

19. Lee H, Davies J and Ryan KJ. 1979. Progesterone receptor in the hypothalamic cytosol of female rats. Endocrinol. 104: 791-800. 
20. Schenborn ET and Karavolas HJ.1983. Hypothalamic progestin receptors: Evidence for two classes of high affinity binding sites. Endocrinol.112: 121-128.

21. Clarke IJ, Cummins JT and de Kretser DM. Pituitary gland function after disconnection from direct hypothalamic influences in the sheep. Neuroendocrinol. 36:376-384, 1983.

22. Clarke IJ, Cummins JT, Findlay JK, Burman KJ and Daughton BW. Effects on plasma luteinizing hormone and follicle-stimulating hormone of varying the frequency and amplitude of gonadotropin-releasing hormone pulses in ovariectomized ewes with hypothalamo-pituitary disconnection. Neuroendocrinol. 39:214-221, 1984.

23. Levine JE, Pau KF, Ramirez VD and Jackson GL. Simultaneous measurement of luteinizing hormone-releasing hormone and luteinizing hormone release in unanesthetized, ovariectomized sheep. Endocrinol. 111:1449-1455, 1982 . .

24. Scaramuzzi RJ, Tillson SA, Thorneycroft IH and Caldwell BV. Action of exogenous progesterone and estrogen on behavioral estrus and luteinizing hormone levels in ovariectomized ewes. Endocrinol. 88:1184-1189, 1971.

25. Kesler DJ, Troxel TR, Vincent DL and Carlin SE. Luteinizing hormone concentrations in anestrous ewes administered various estrogens. Theriogenology 13:231-235, 1980.

26. Bolt DJ, Kelly HE and Hawk HW. Release of LH by estradiol in cycling ewes. Biol. Reprod. 4:35-40, 1971. 
Figure 1: Concentration of LH for GnRH vs saline infusion in stalk (SS) and sham (SH) transected ewes from day 5 to day 10 of the estrous cycle.

Degrees of Freedom Error = 69, Mean Square Error = 0.194.

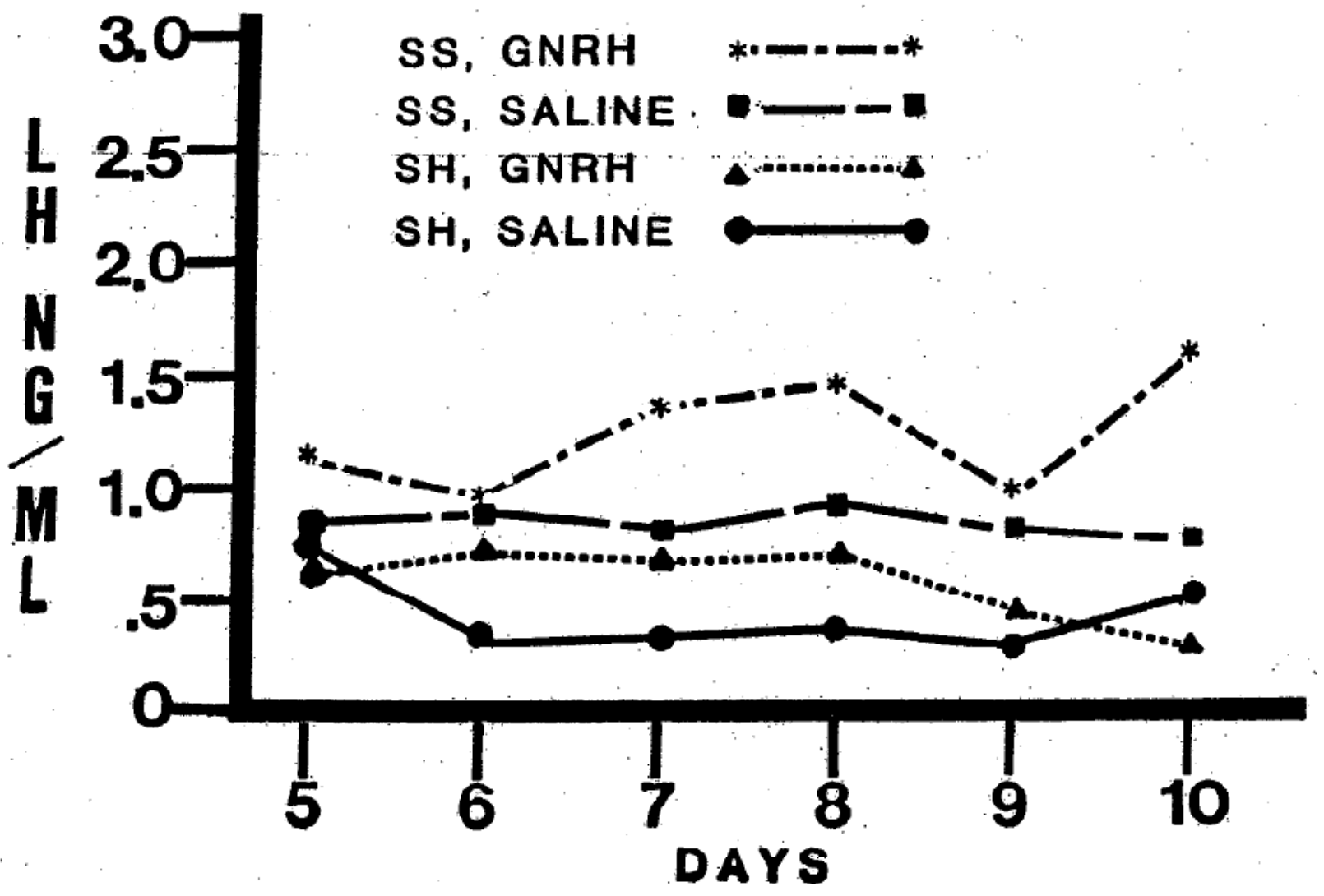


Figure 2: Concentrations of progesterone for GnRH vs saline infusion in stalk (SS) and sham (SH) transected ewes from day 5 to day 20 of the estrous cycle.

Degrees of Freedom Error $=98$, Mean Square Error $=0.832$.

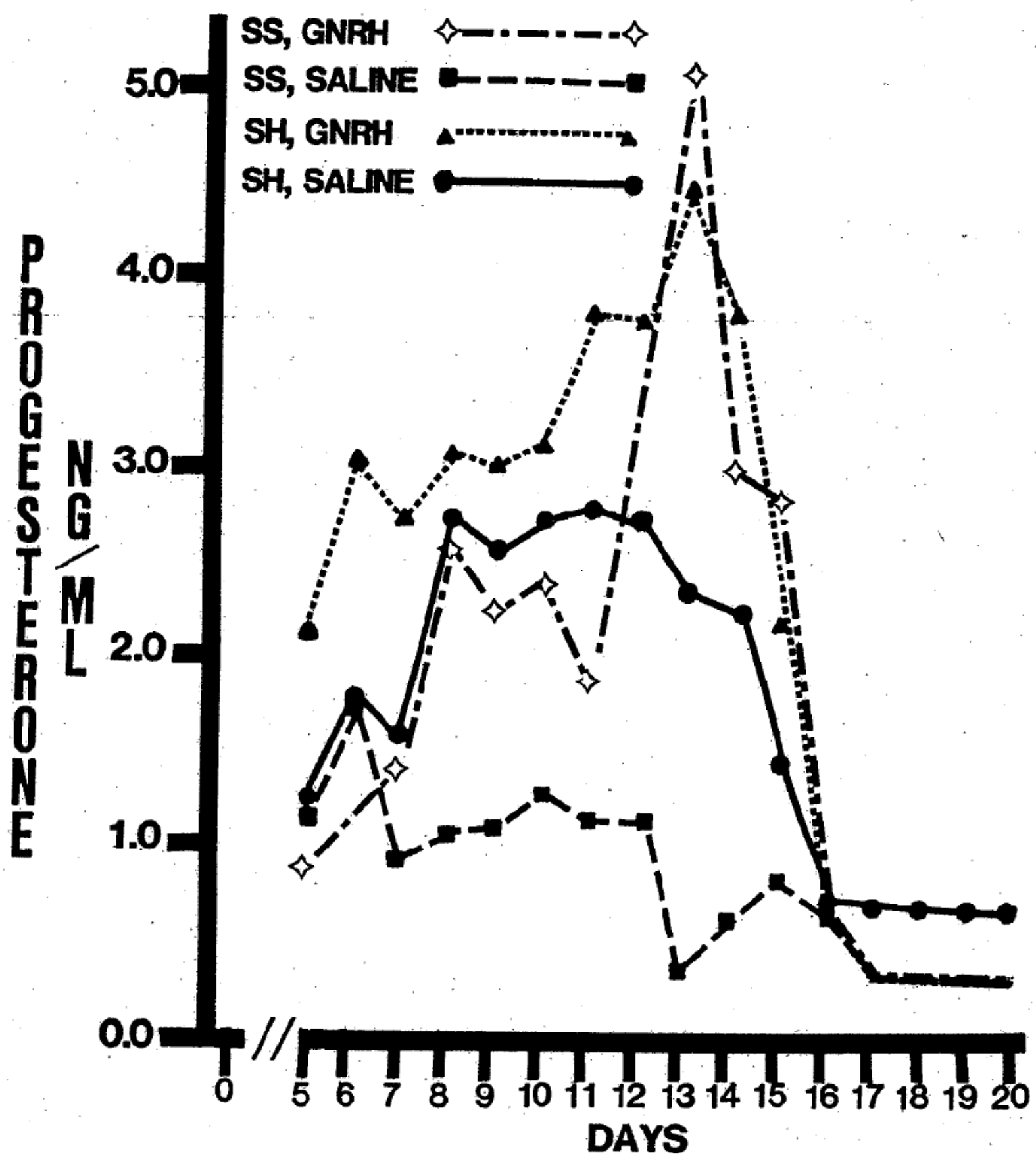

